\title{
A NEW APPROACH TO THE GEOLOGICAL CONFIGURATION OF THE LOWER CRETACEOUS TUCANO AND JATOBÁ BASINS, NORTHEASTERN BRAZIL
}

\author{
LUCIANO P. MAGNAVITA* and JOSÉ A. CUPERTINO*
}

\begin{abstract}
Until recently, the Lower Cretaceous Recôncavo-Tucano-Jatoba Rift was interpreted as being a system of basins connected since the beginning of rifting and filled by a fluvio-deltaic-lacustrine system which prograded from north to south. In this work, based on field observations, gravity data, new models for the evolution of continental rifts, and comparison with the East African rifts, the basins are interpreted as a series of half-grabens with disconnected depocenters, and which evolved separately. The isolation was effected by transfer faults - the Itapicuru and Vaza-Barris faults - which cut the rift in a NW-SE direction and are, principally the Vaza-Barris fault, controlled by basement anisotropy. According to this model, the majority of drilled wells were located on stable platforms, without suitable conditions to generate hydrocarbons, and thus the Tucano and Jatobá basins are not adequately explored.
\end{abstract}

\begin{abstract}
RESUMO Até recentemente, acreditava-se que o Rifte do Recôncavo, Tucano e Jatobá do Eocretáceo teria evoluído como um sistema de bacias interligadas desde o início do rifteamento, sendo preenchido por um sistema flúvio-deltaico progradante de norte para sul. Neste trabalho, com base em evidências de campo, dados gravimétricos bem como nos novos modelos propostos para a evolução de riftes continentais e pela comparação com os riftes africanos, postula-se a evolução da fossa baiana a partir de "meios-grábens", resultando em sub-bacias com depocentros isolados por falhas transcorrentes do tipo de transferência - as falhas do Rio Itapicuru e do Rio Vaza-Barris. Estas falhas, notadamente a de Vaza-Barris, seriam controladas por antigas direçóes de fraqueza do embasamento, seccionando o rifte na direçāo NW-SE. Dentro desta nova concepção, a maioria dos poços a norte do Tucano Sul foi perfurada em áreas estáveis, sem condiçōes de geração adequadas. Portanto, as bacias do Tucano Central, Norte e Jatobá ainda nāo foram convenientemente testadas.
\end{abstract}

INTRODUCTION The Tucano and Jatobá basins are located in the northern portion of the Recôncavo Rift System, comprising an area of about $35,000 \mathrm{~km}^{2}$ (Fig. 1). The Tucano Basin is divided in three subbasins, known as South, Central, and North Tucano, which are set apart from one another by features transversal to the rift trend.

The knowledge is quite heterogeneous from one basin to the other and decreases to the north. The majority of wells drilled in the Tucano Basin were located in South Tucano and discovered the Conceição, Quererá, and Iraí gas fields. Seismic-reflection data are limited to the southern portion of Central Tucano; to the north, there are only gravimetric, aeromagnetic, and seismic-refraction surveys, plus the information from 19 wells.

STRATIGRAPHY The basins include sediments deposited from the Paleozoic to the Cenozoic (Fig. 2). The Paleozoic sediments are preserved in North Tucano and Jatoba basins,outcropping along the eastern boundary of the rift. The strata include Siluro-Devonian alluvial sandstones of the Tacaratu Formation and Carboniferous and Permian sandstones and shales of the Curitiba Formation and Santa Brígida Formation, which are preserved in the Santa Brígida Graben, and requiring further studies to explain their sedimentological genesis.

Pre-rift red beds include the Brotas Group and the Itaparica Formation, which extended over present rift limits. The pre-rift phase finished with lacustrine black shales - the Tauá Member of Candeias Formation.

The rifting began during the Neocomian, and is characterized by a thick conglomeratic wedge of Salvador Formation, deposited close to the border major faults. During the starving basin phase the deep-lake shales of the Candeias Formation were deposited with some turbidites in the depocenters. Later on, the subsidence rate decreased and the rift was filled by a prograding delta system (Ilhas Group), followed by fluvial sediments of the Massacará Group. An unconformity separates the rift sediments from alluvial sandstones of the Marizal Formation deposited during the
Aptian. Finally, continental deposits of the Barreiras Formation developed during the Cenozoic.

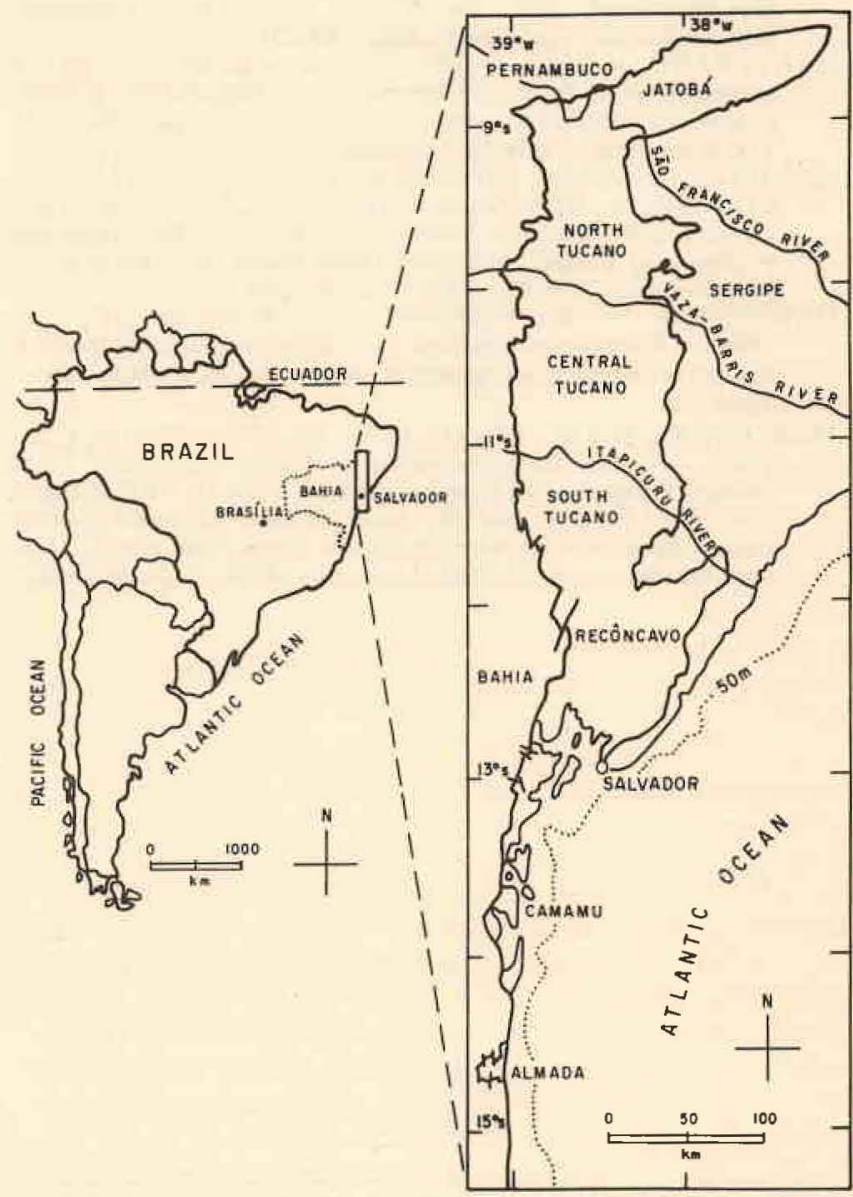

Figure 1 - Situation map 


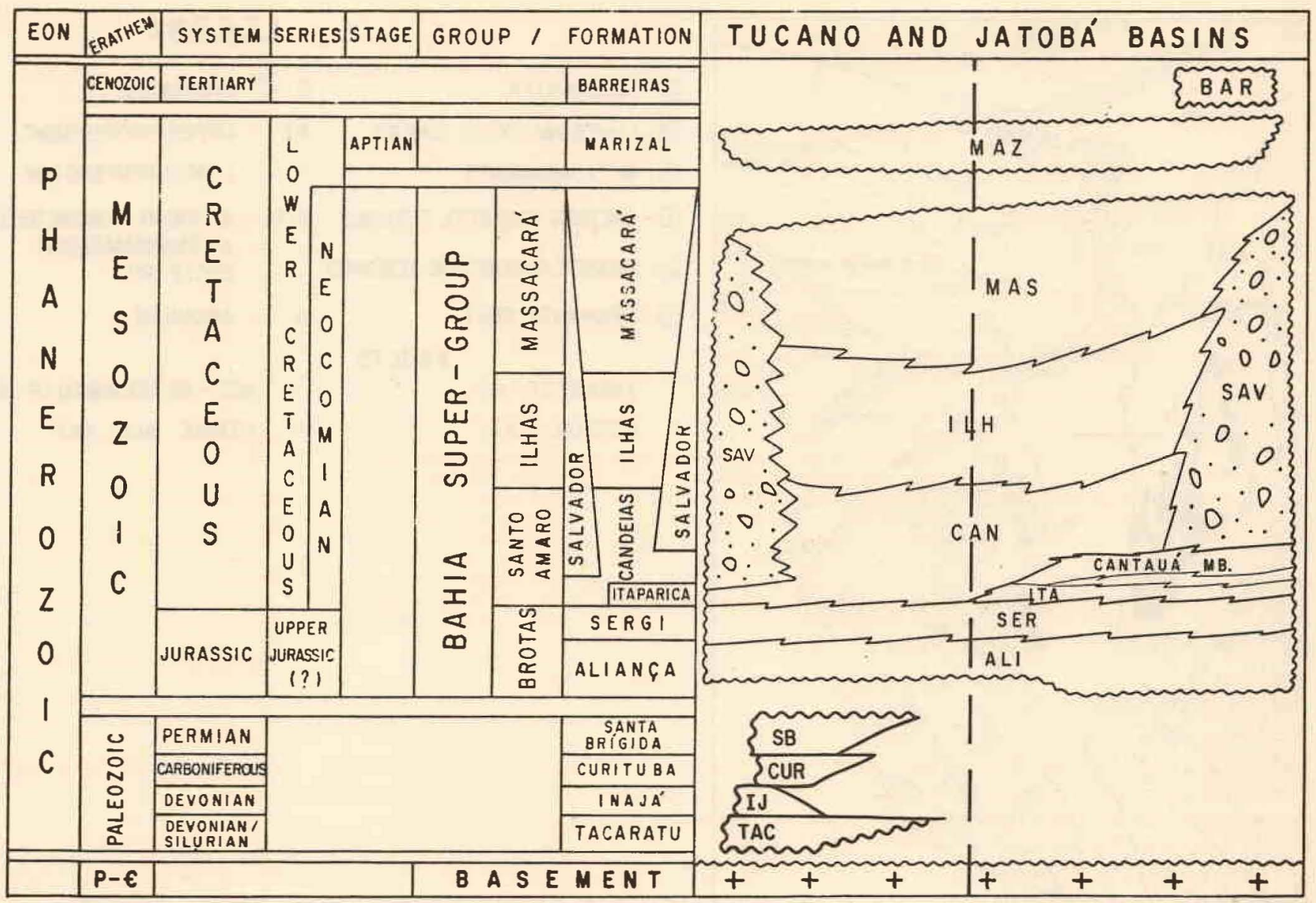

Figure 2 - Stratigraphic column of Tucano and Jatobá basins

REGIONAL GEOLOGY The Recôncavo - Tucano Jatobá rift is situated over terrains of Arquean to Paleozoic age, which have quite different mechanical behaviour. Basement fabric control was fundamental on the evolution of the tectonic framework of the basins. The planar anisotropy is related to schistosity, lithological contacts, faults, and shear zones (Davison \& Arthaud 1987) reactivated during the rifting in the Lower Cretaceous. This basement control is also observed in the East African rifts (Le Fournier 1985).

Many ancient basement structures controlled the rift skeleton (Fig. 3):

a. the Recôncavo half-graben is guided by the NE arm of the Atlantic granulitic belt, parallel to which the Gondwana break occurred;

b. the rift is oriented N-S, parallel to greenstone belts and lineaments in São Francisco Craton (Milani 1985);

c. the sharp northern termination of Jatobá Basin against a shear zone related with the Pernambuco Lineament, a Precambrian ductile shear zone;

d. the Itaporanga Transpressional Megazone cuts across the rift in a NW-SE direction and determines a change in basin asymmetry along the Vaza-Barris River, where several normal faults trending NE are present (Fig. 4). In detail, the fault zone is quite silicified and the movement is distributed along small faults. In general, two sets of faults are present: one trending NE and the other oriented to NW.

The Upper Proterozoic metasediments of the Sergipano Folded System did not have, at a first look, any influence on the direction of opening of the rift. These rocks probably represent a thin basement cover, and the deeper structures of the craton would be responsible in controlling the rifting.

The distribution of Paleozoic sediments on the eastern border of North Tucano and Jatobá basins suggests that some subsidence took place during the Paleozoic.

STRUCTURAL FRAMEWORK The information about the structural framework is quite uneven from one subbasin to another, because the majority of wells and seismic-reflection data are confined to the southern part of the rift. The inference increases northward of South Tucano subbasin since the interpretation is based on refraction and gravity surveys.

Rift Morphology The rift comprises a series of half-grabens which extend into the continent in a N-S direction, with a sharp change to a ENE-WSW direction in the Jatobá Basin. The asymmetrical graben dip to SE from the Recôncavo Basin until the Tucano Central subbasin, and change their dip to NW, northward of the Vaza-Barris Arch (Fig. 5).

The southern boundary of Tucano Basin is the Apora High, which is oriented to NE. The South Tucano subbasin is marked by a N3OE fault set, with antithetic domino style, dipping to west (Fig. 6). Close to the eastern limit, a distributary fault system of listric fan geometry parallel to the Inhambupe Fault is responsible for the great subsidence that occurs in that region. Sintectonic conglomerates are present close to this major fault. The subbasin subsides progressively to NE towards the Itapicuru River Fault, which has a NW-SE orientation. In that area, two major lows are defined: the Olindina and Inhambupe lows, with more than $6 \mathrm{~km}$ of sediments (Fig. 7).

The Central Tucano subbasin is situated north of the Itapicuru Fault, and the faults in it are oriented N-S. Two 


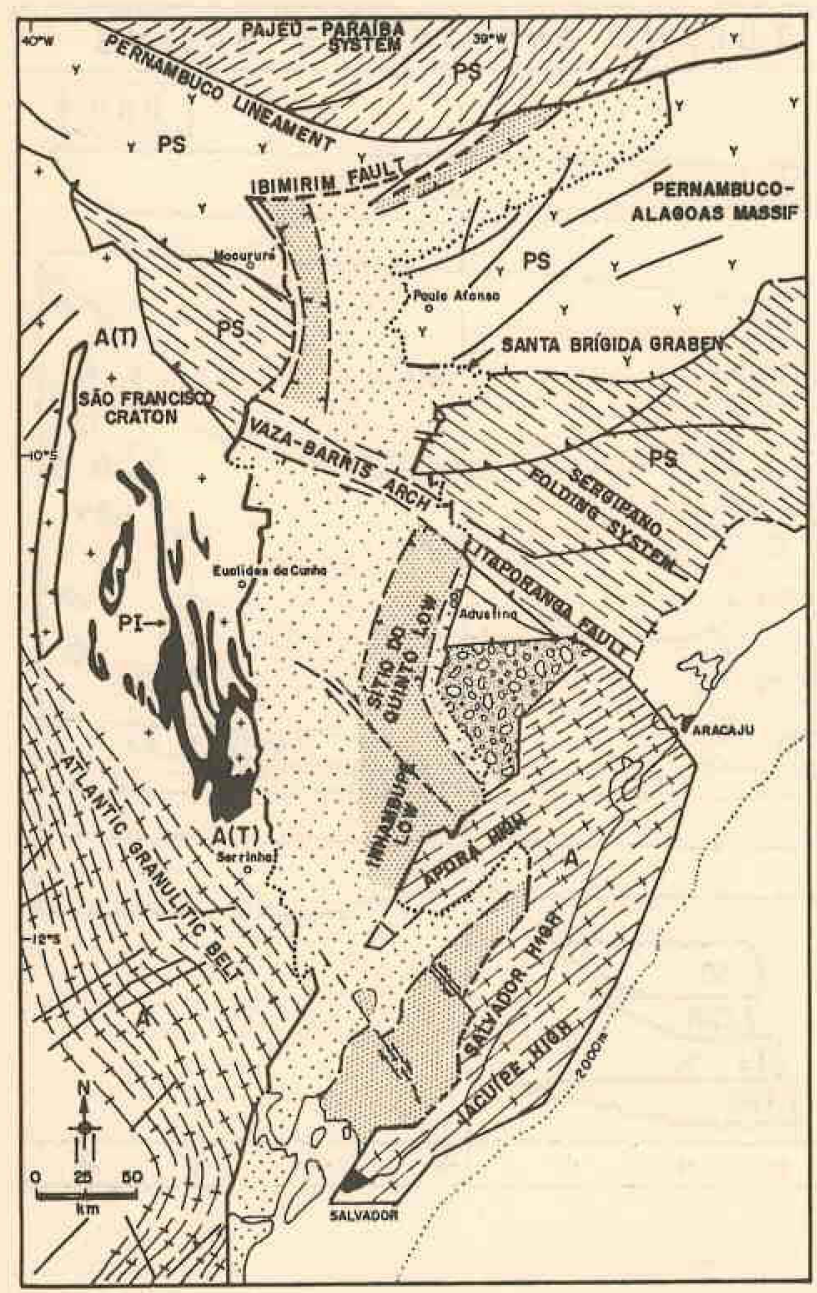

LEGEND

圈 DEPOCENTER

圈 LOWER PALEOZOIC COVERS

METASSEDIMENTS

(1 GNEISSIC-MIGMATITE TERRANS

(1) GRANITE-GREENSTONE TERRANS

P-€ - PROVINCES

凤 GRANULITIC BELT

FAULTS

$\backslash$ THRUST $(P-€)$

$\backslash$ NORMAL (K)

NOT - DETERMINED $(P-€)$

NV STRIKE SLIP (K)

Figure 3 - Geological regional map showing the relation between the rift structural framework and the basement (modified from Milani 1987)

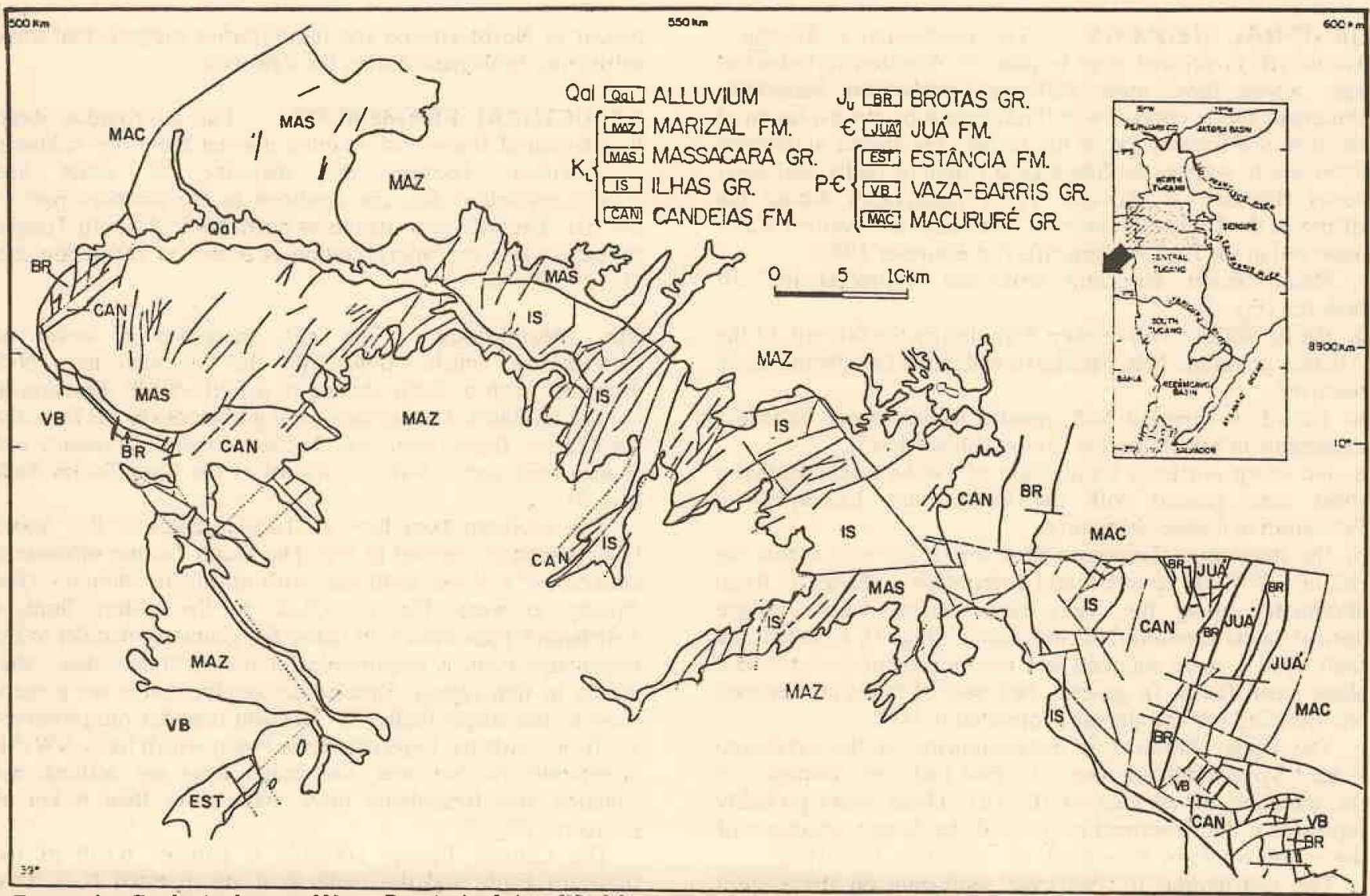

Figure 4 - Geological map of Vaza-Barris Arch (modified from Della Piazza and Muhlman, 1963) 
stable areas are defined: the Quilombo Platform on the east and the Umburana Platform on the other side. The latter occurs along the western portion of the subbasin, and the majority of existing wells were drilled on it. As in South Tucano, a tilt to NE towards the Vaza-Barris Arch originates the Sítio do Quinto Low, where gravimetric inversions estimate more than $10 \mathrm{~km}$ of sediments (Fig. 8).

The Vaza-Barris Arch is a structural arch with shallow basement. It marks a tortion in the rift and this is due to the action of a transfer fault (in the sense of Gibbs 1984). Stratigraphic data on the arch and gravimetric modelling show its antiform character since the beginning of rifting (Fig. 9).

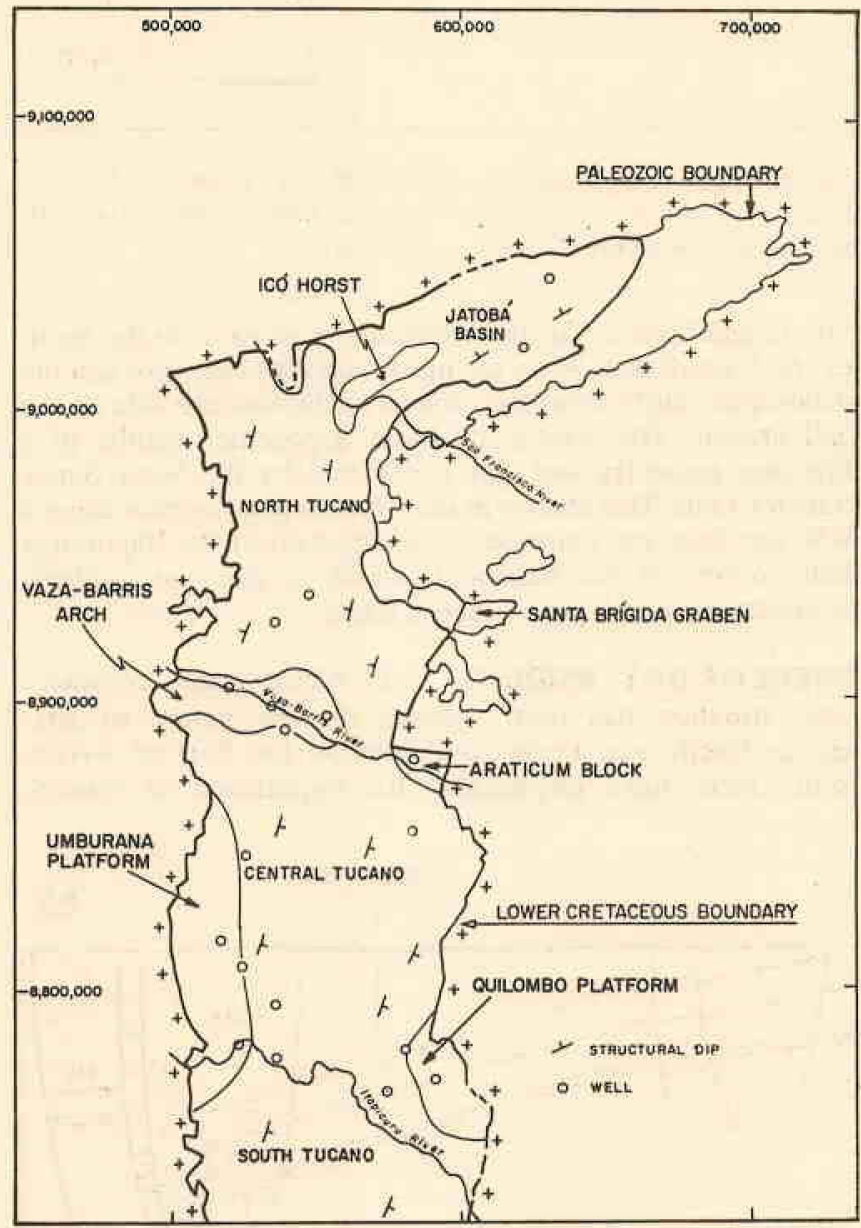

Figure 5-Morphologic features of Tucano and Jatobá basins
A small triangular block, known as the Araticum Block, occurs in the eastern portion of Central Tucano and marks the first outcrops of the Brotas Group on the eastern side of the rift.

To the north of the Vaza-Barris Arch, the North Tucano subbasin reveals a more complex structural pattern, developing two depocenters. The available data do not show evidence of platforms and paleozoic sediments outcrop in its eastern margin. Contrasting with the southern basins, this subbasin is tilted to NW, and there is a thick deposit of sintectonic fanglomerates close to the master fault in its western boundary.

The Jatobá Basin is the shallowest one in the rift system,

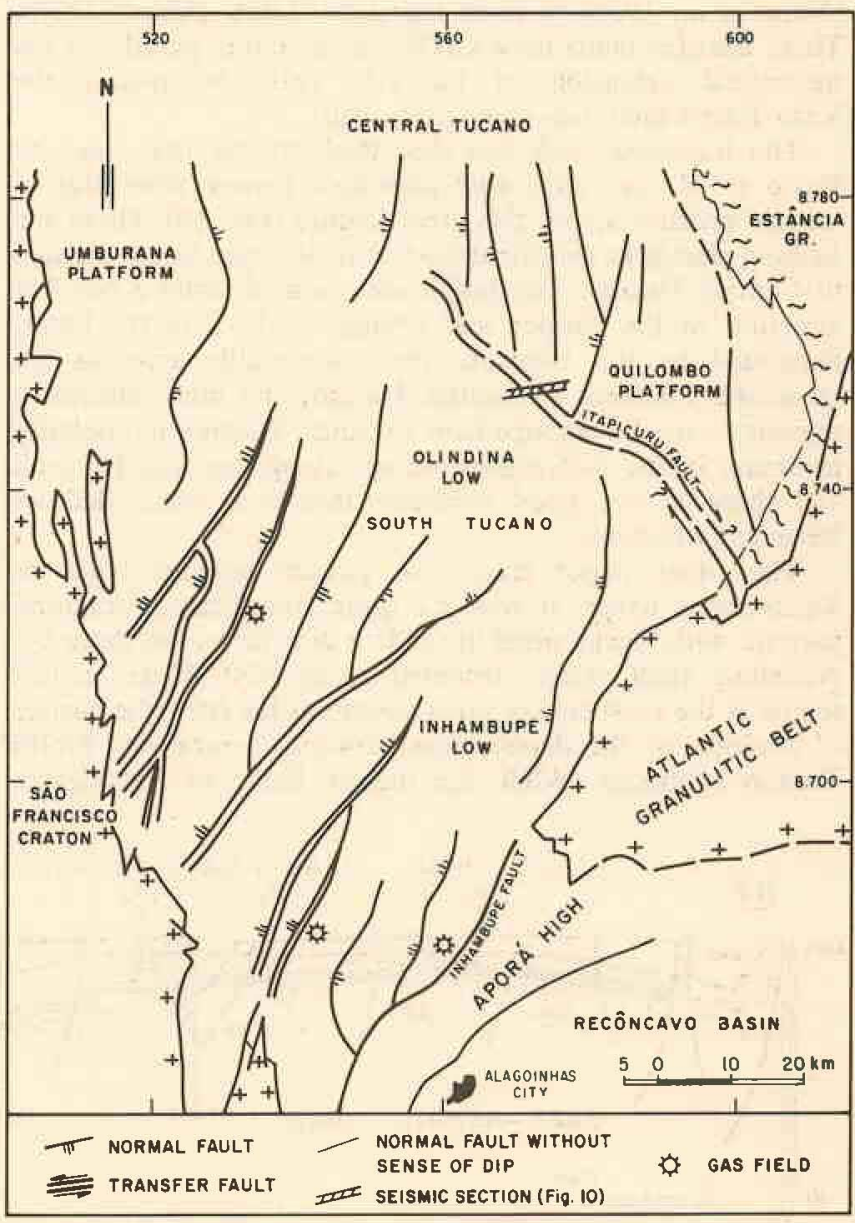

Figure 7 - Structural framework of South Tucano Subbasin based on seismic-reflection data

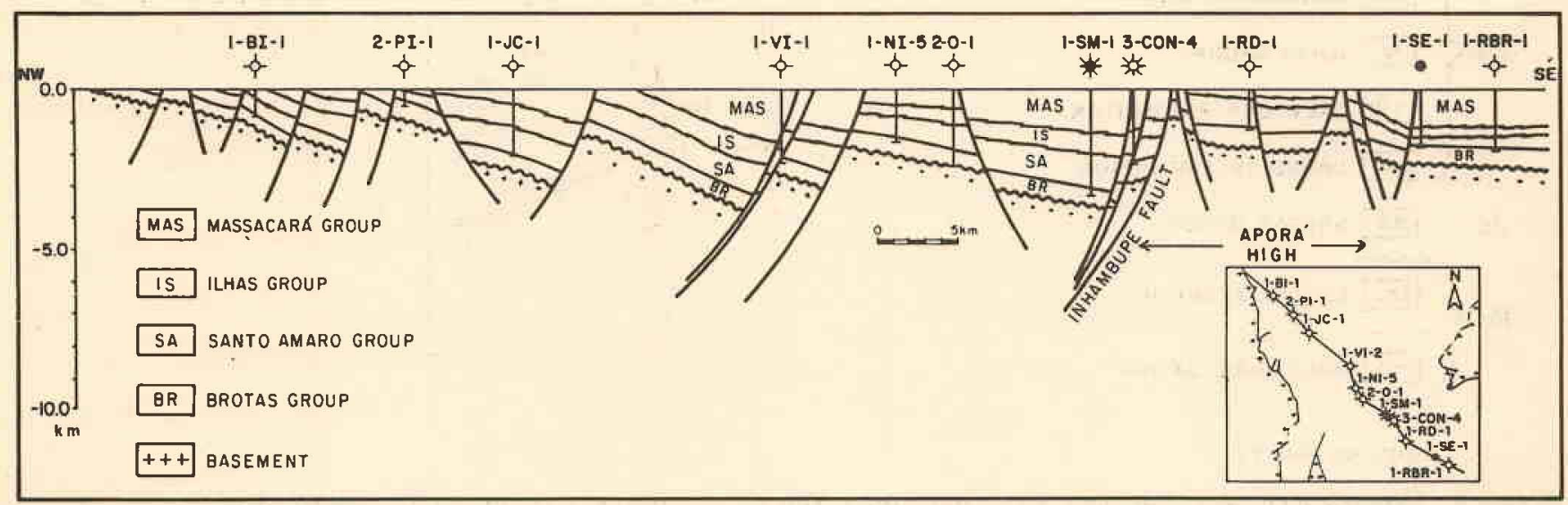


and its depocenter is close to the Ibimirim Fault near the northern limit. As in North Tucano, paleozoic sediments outcrop in the SSE basin boundary. In the middle of the basin is the Icó Horst, a structural high quite evident in gravimetric maps.

Major Transversal Features Along the rift, structural transversal features are scarce. In the Tucano Basin, there are two large oblique shear zones: the Itapicuru River Fault and the Vaza-Barris Arch. The former separates South and Central Tucano subbasins, while the latter set apart Central from North Tucano. Recently, these fault zones were interpreted by Milani \& Davison (1987) as transfer zones, although they were described before as strike-slip faults (Netto et al. 1985) or even transform faults (Milani 1985). These transfer faults have a NW-SE direction, parallel to the theoretical extension of the rift, and are, mainly the Vaza-Barris fault, basement controlled.

The Itapicuru Fault was described, by the first time, by Netto et al. (op. cit.), who identified flower structures in seismic profiles across this great feature (Fig. 10). There is a striking change in the orientation of faults from South Tucano to Central Tucano. The faults are oriented along a NE-SW direction in the former and change to $\mathrm{N}-\mathrm{S}$ in the latter. Separated by the Itapicuru Fault are stable areas as the Quilombo Platform in Central Tucano, and higly subsident, regions as the Inhambupe Low in South Tucano. No polarity inversion in the half-graben occurs along this transfer fault and there is not good evidence that it is controlled by basement structures.

The other major transverse feature appears close to Vaza-Barris River. It shows a quite complicated structural pattern, with blocks tilted in random directions, but there is a prevailing fault system oriented along $\mathrm{N} 30^{\circ}-50^{\circ} \mathrm{E}$. In this region is the most conspicuous feature of the rift - the change of position of the depocenters between Central and North Tucano subbasins. While the master faults of Recôncavo,

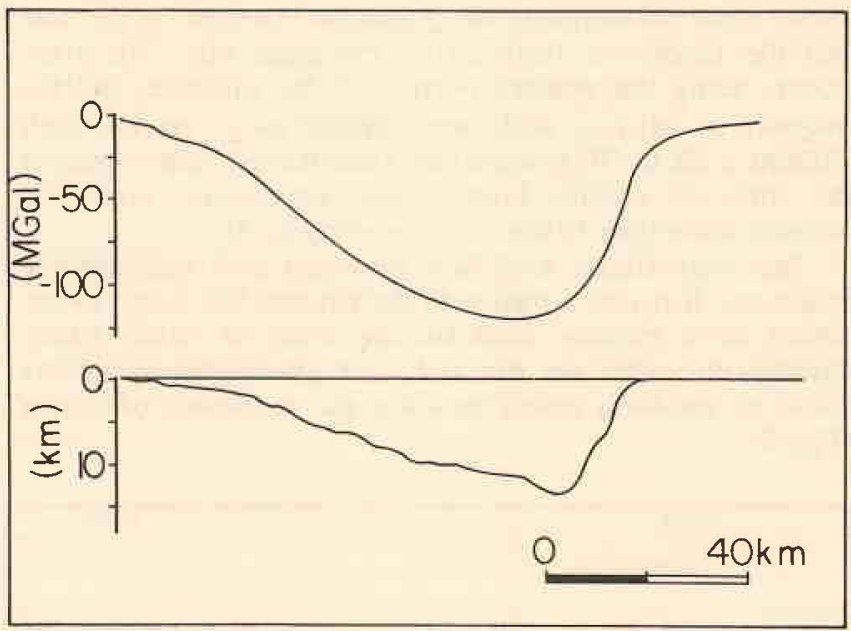

Figure 8 - Gravimetric inversion in Central Tucano Sub-basin. In the depocenter occurs more than $10 \mathrm{~km}$ of sediments (see figure 14 for localization)

South, and Central Tucano basins dip westward, to the north of the Vaza-Barris Arch the main fault dips eastward and the depocenter shifts from the eastern to the western side of the half-graben. This switch of basin depocenter results in a flip-flop geometry and this is effected by the Vaza-Barris transfer fault. This change in the rift symmetry occurs along a NW direction and coincides with direction of the Itaporanga fault system in the basement, which is also the southern boundary of the Sergipe-Alagoas Basin.

PRESENT-DAY MODELS In recent years, considerable attention has been focused on the nature of rifting in North Sea, Persic Gulf, and in the East of Africa. Some ideas have emphasized the importance of wrench
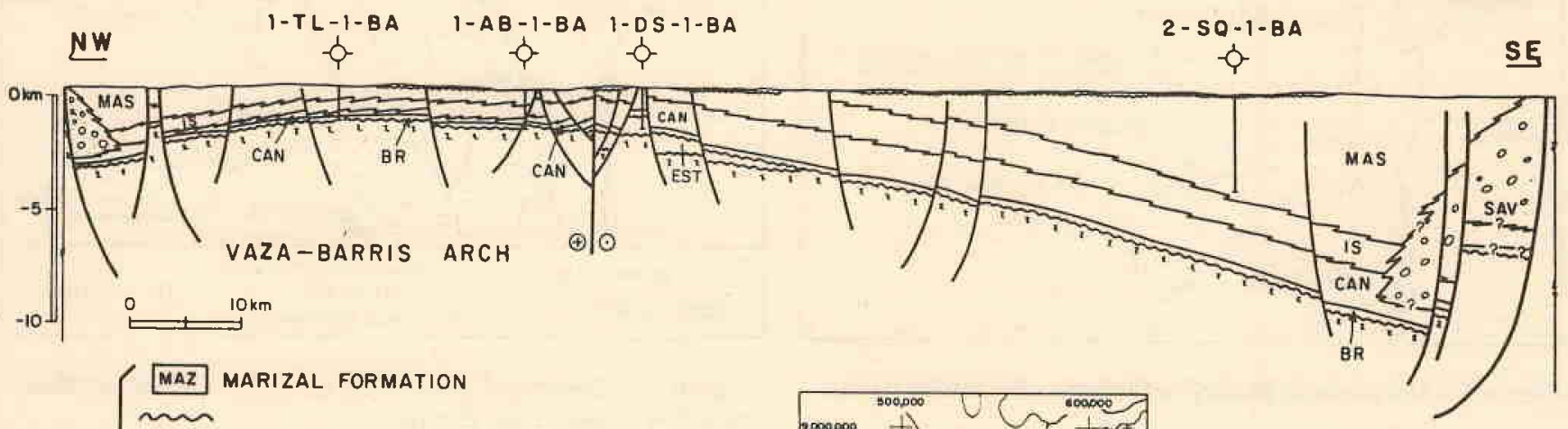

$K_{I}\left\{\begin{array}{l}\text { MAZ MARIZAL FORMATION } \\ \text { MAS MASSACARA GROUP } \\ \text { SAM SALVADOR FORMATION } \\ \text { CAN CANDEIAS FORMATION }\end{array}\right.$
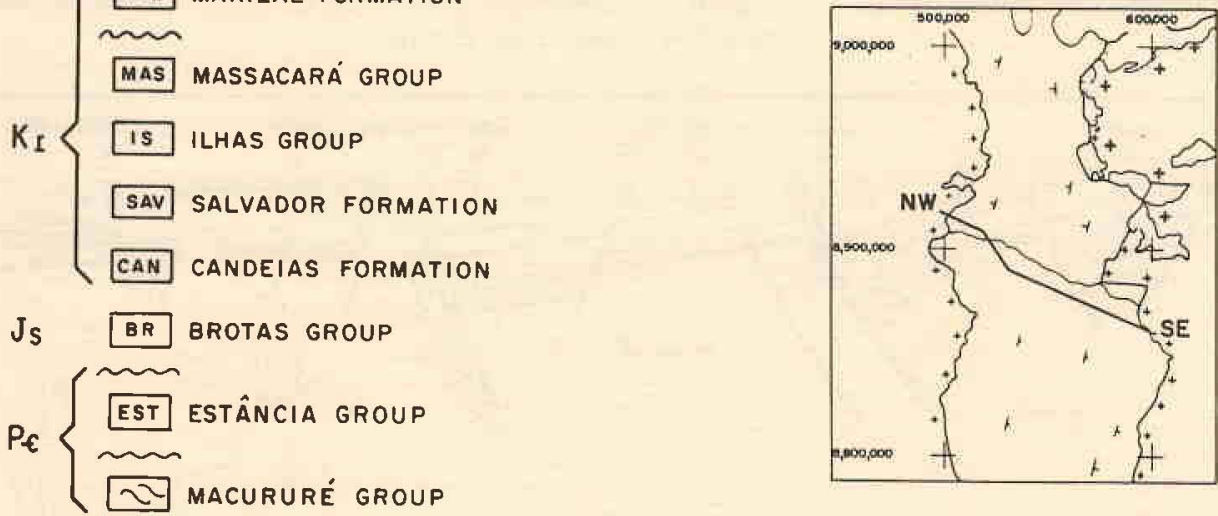

〜UNCONFORMITY

Figure 9-Geological cross-section along Vaza-Barris area. Note the non-balanced section on Vaza-Barris Arch 
tectonics (Wilcox et al. 1973), the concept of linked extensional systems and transfer faults (Gibbs 1984), and more recently the model of rifting from detachment faulting (Wernicke 1985, Lister et al, 1986). These concepts were applied by many authors who worked in the Recôncavo-Tucano-Jatobá Rift.

Recent works on the Recôncavo-Tucano-Jatobá Rift Over the years, the Recôncavo-Tucano-Jatobá basins have been interpreted to be the result of extensional rifting, with basins connected since the beginning of the faulting and filled by a fluvio-deltaic-lacustrine system that prograded from north to south as a result of a failed arm of the South Atlantic opening (Ponte et al. 1978).

Netto et al. (1985) described the structural framework of South Tucano and concluded that this subbasin has lower paleogeotermic gradients than the Recôncavo Basin.

Szatmari et al. (1985) proposed that the evolution of this portion of the Brazilian continental margin, and the opening of the rift, was caused by an counterclockwise rotation of a rigid microplate which they called the "East Brazilian Microplate".

Milani (1985), based on the model proposed by Szatmari et al. (op. cit.), emphasized the role of the pre-existing basement weakness, and admited crustal stretching in a NW-SE direction as responsible for rift opening. He high-lighted the importance of shear zones which separate the rift in subbasins, each independent from one another (Fig. 11).

Cohen (1985) suggested that the rift would have been formed as a megatension gash in response to a NE sinistral shear zone. This author based his conclusions on the orientation of faults mapped at surface level in the Recôncavo
Basin, and interpreted three sets of faults (N30E, N13W, $\mathrm{N} 37 \mathrm{~W}$ ) as fiting within a shear diagram. Nevertheless, one fails to see the NE faults as strike-slip faults, since seismic and field evidences, as well as their normal activity during sedimentation, show that they are essentially gravitational.

Ussami (1986) applied a detachment model to the evolution of the Tucano and Gabon basins. Unfortunately, some fundamental tectonic aspects were missed, $e . g$. the change in basin symmetry across the Vaza-Barris Arch, which would imply a change in the direction of the detachment (Fig. 12). The answer to this problem could be given by a deep seismic-reflection survey, which is not available at present.

Gravity modelling (Fig, 13) shows a crustal thinning with an elevated Moho chose to the moster limiting faults, and we can expect a large lateral and vertical heat flow into the graben margins during the rift event. This crustal thinning was also verified by Milani (1985) and Cohen (1985).

Comparison with African Modern Rifts The features observed in the Cenozoic rifts of Eastern Africa are quite similar to those observed in the Tucano and Jatobá basins, and some correlations between them are possible.

The fundamental tectonic unit of the East African Rifts is the half-graben. This framework is typical of the Tucano and Jatobá basins. These asymmetrical graben have a major fault (or a fault system) in their steeper margin (e.g. Inhambupe Fault at South Tucano) with sintectonic fanglomerates (Le Fournier 1985) in the downthrown block. These faults become listric downward and can show horizontal movement; the fault evolves to a distributary fault system with the onset of subsidence.

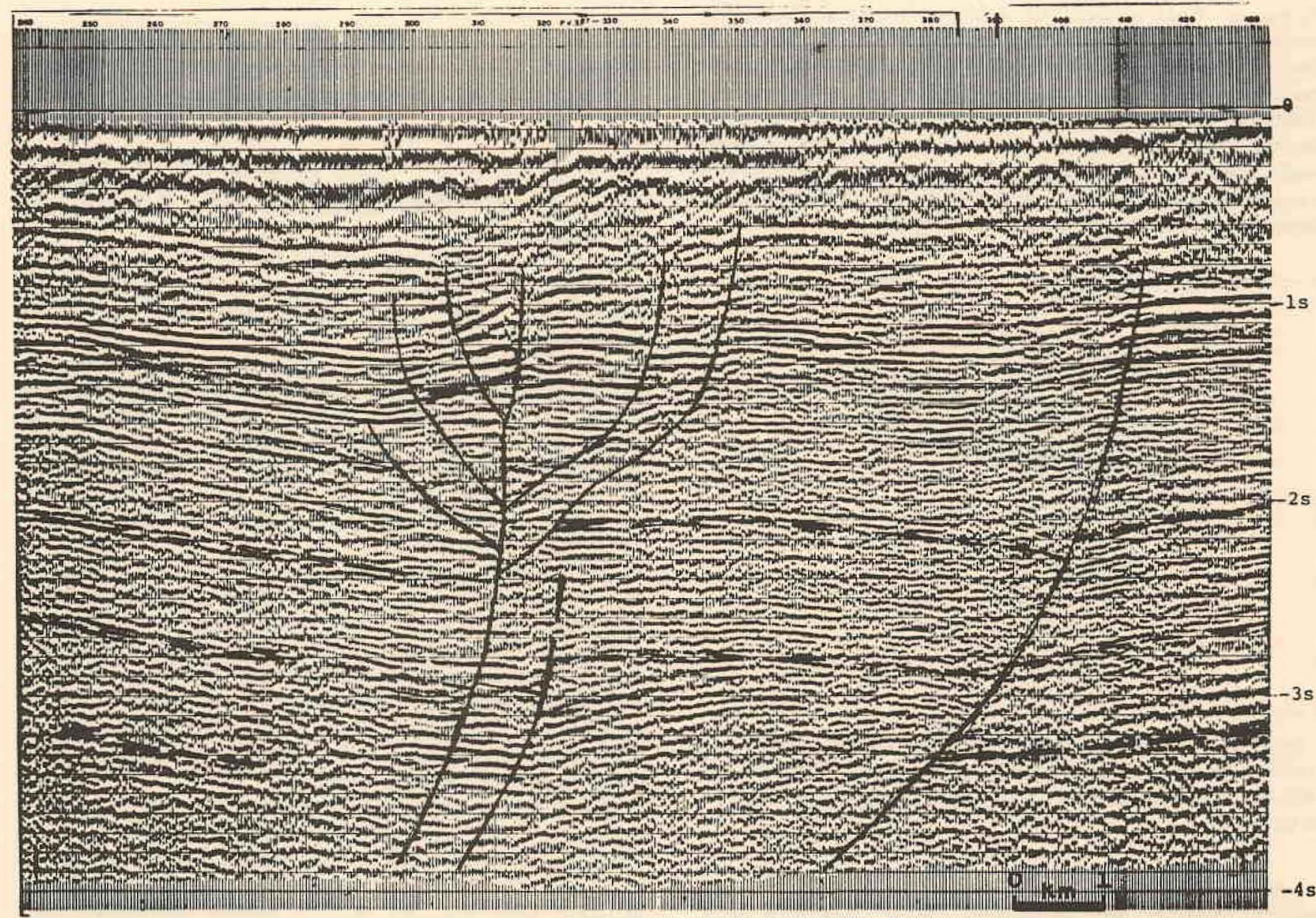




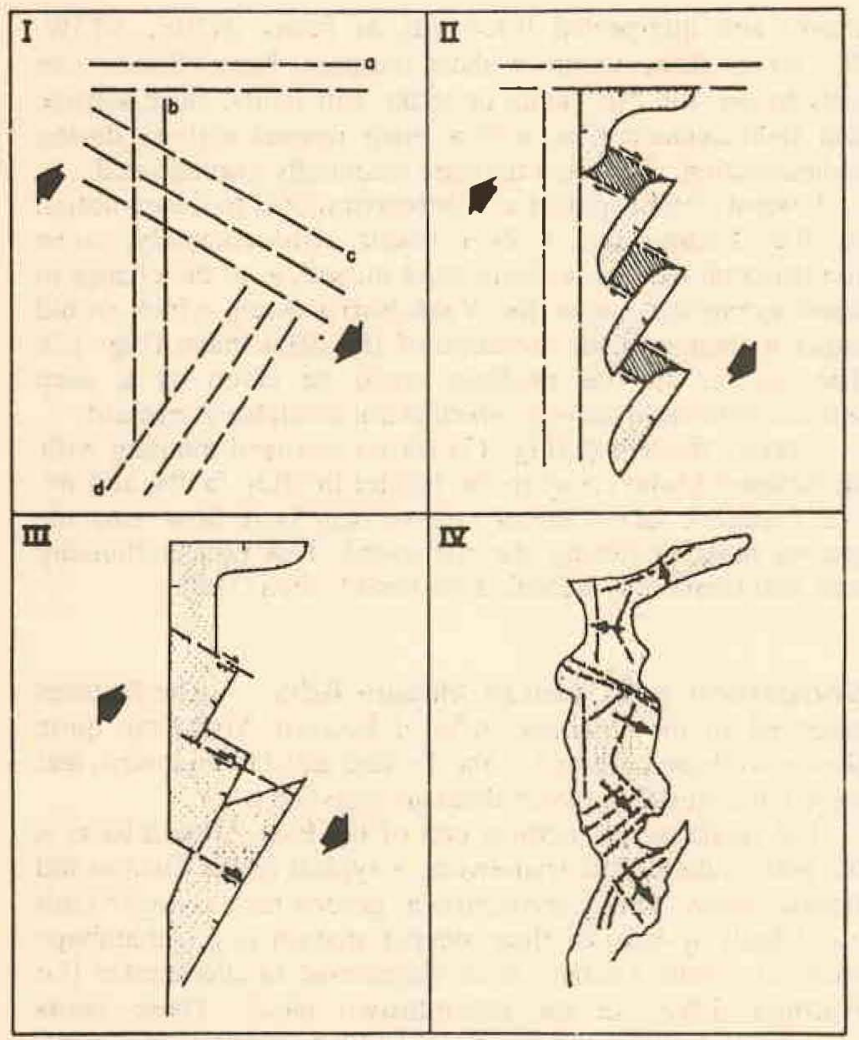

Figure 11 - Tectonic evolution of Recôncavo-Tucano-Jatobá Rift. I. Main Precambrian lines of weakness in the region: a) Pernambuco-Alagoas Massif; b) São Francisco Craton; c) Sergipano Folding Belt; d) Atlantic Granulitic Belt. The arrows indicate the Cretaceous stress field. II. Along crustal lines of weakness half-grabens are formed and large normal faults develop in one border; in regions of lateral overlap (hachured areas), occur shear stresses. III. The half-grabens become broad due to flexure in their borders and transcurrent faults appear cutting across the sedimentary deposits. IV. Present configuration. The small arrows indicate the structural basement dip in each subbasin (Milani 1985)

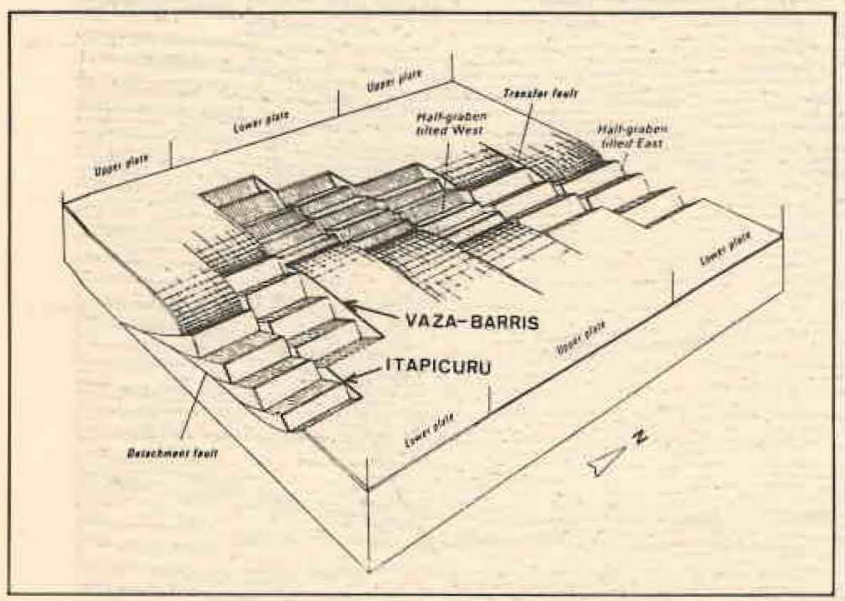

Figure 12 - Possible configuration of Tucano sub-basins isolated by transfer faults. There is a good correspondence with the structural style of Tucano Basin (adapted from Lister et al. 1986)

At the other margin, we do not see large faults, but rather smooth flexures and structurally stable platforms (e.g. Umburana Platform); on these platforms, lateral fluvio-deltaic systems feed the depocenters where can turbidites be deposited. Within the half-graben, antithetic and sintethic faults are observed, but the former are more common in Lake Tanganyika (Rosendhal et al. 1986).

The half-grabens change the structural dip along the rift at a transfer zone, which can be transpressional, and internal highs are formed (e.g. Vaza-Barris Arch), separating different subbasins. In map view, the basins show a flip-flop geometry, as observed in Central and North Tucano (Fig. 14). These structural highs have only a thin sedimentary cover,and they are eventually fully covered at the end of rift evolution.

Some symmetrical grabens are restrict to transition zones between two subbasins which show a central arch (Rosendhal et al. (1986); this fact is noted in the transition zone of the Vaza-Barris Arch. Another symmetrical situation appears when there is a shift on the rate of subsidence in one subbasin, in the same way as the movement of a teeter-totter but, in this case, unconformities are common.

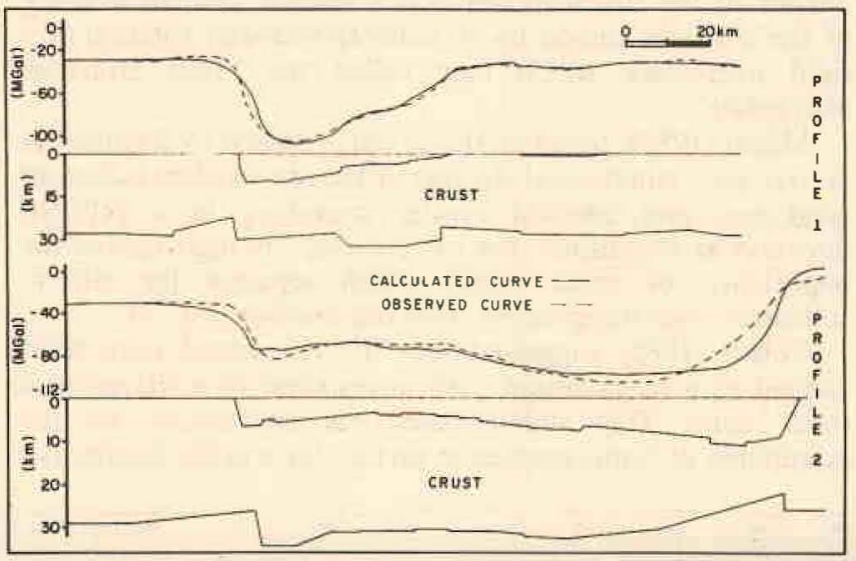

Figure 13 - Gravity modellings showing the crustal thinning under basin margins (see figure 14 for localization)

In respect to the tecto-sedimentary evolution, Le Fournier (1985) recognizes three stages which can be correlated with the stratigraphic section of the rift phase of Tucano and Jatobá basins (Fig. 15).

Stage 1: Phase of crustal stretching and formation of a broad and shallow basin filled by arenous sediments, with small normal faults. This stage occurred during the Brotas Group deposition.

Stage 2: Crustal stretching with rupture and tilting of blocks. The extension zone becomes narrow, the fluvial sedimentation ceases, and the sedimentary deposits are eroded on the border of the tilted blocks. At the downthrown block of normal faults small lakes and swamps are formed. The vertical throw is moderate. This stage probably took place during the deposition of the Itaparica Formation and the Tauá Member of Candeias Formation.

Stage 3: Crustal stretching with colapsed blocks. The faults have great vertical throw and subsidence increases. Deep lacustrine deposits with turbidites are common. The tectonic activity is close to the depocenter and a thick conglomerate sequence spreads over the basin margin. This stage coincides with the deposition of the Candeias Formation and Salvador Formation. Afterwards, the subsidence/deposition ratio decreases gradually and a fluvio-deltaic system fills the basin (Ilhas Group and Massacará Group).

The sedimentary process at each subbasin is similar but its result may not be stratigraphically correlatable due to diferences in time, subsidence and clastic supply (Rosendhal et al. 1986); in this way, a lack of temporal correlation, different litologies, and distinct deposit distributions are expected. 
CONCLUSIONS The main conclusions drawn are:

- the Tucano-Jatobá Rift evolved as a series of disconnected subbasins isolated by transfer faults;

- the rift was formed by crustal stretching in a NW-SE direction and was aborted during the separation of South America and Africa;

- the basement anisotropy was fundamental in the evolution of the structural framework of the basins; this control is evidenced by the tortion along the Vaza-Barris Arch and by the direction of the master faults that border the rift;

- each subbasin has a characteristic half-graben geometry. The South and Central Tucano subbasins are quite similar, but the fault direction changes abruptly to the north of the Itapicuru River. In North Tucano, the structural pattern seems to be more complex;

- the sedimentary processes are analogous in each subbasin; however, chronologic differences, unequal subsidence rates, and distinct clastic supplies may handicap the stratigraphic correlation;

- there was not a thermal subsidence phase, but gravimetric modelling shows crustal thinning close to the borders and near the depocenters;

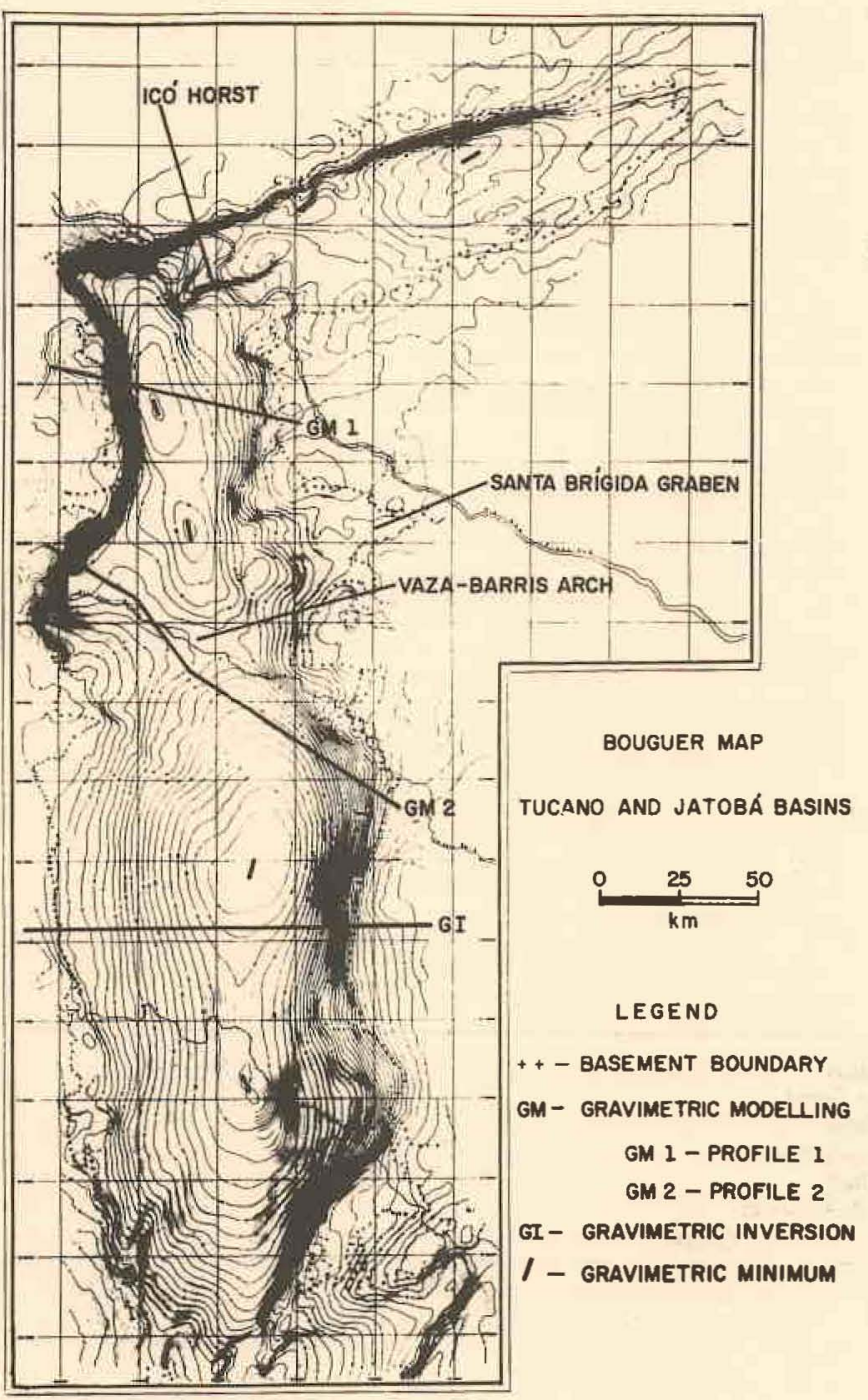

Figure 14 - Bouguer map. Observe the switch of depocenter between Central and North Tucano subbasins

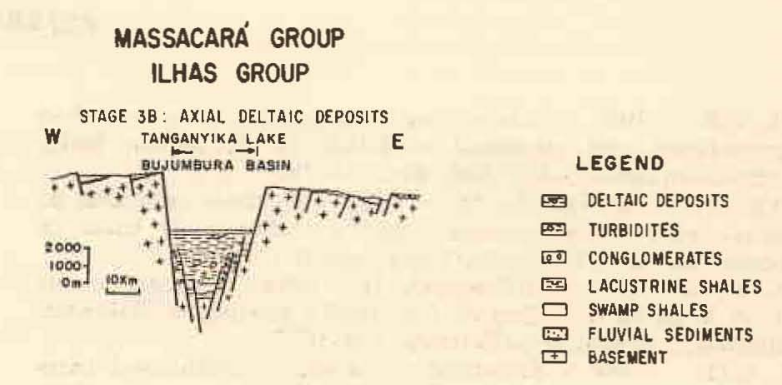
MIDDLE AND UPPER CANDEIAS FORMATION
STAGE 3A: STARVING BASIN

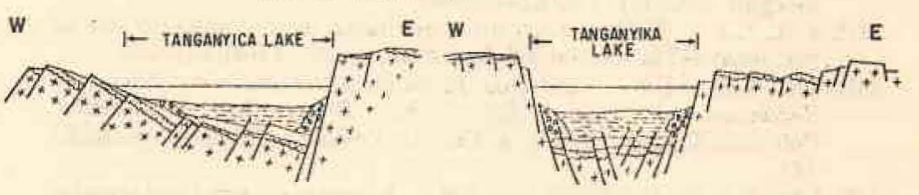

ITAPARICA FORMATION

TAUA' MEMBER

wNW

STAGE 2: LAKE BANGWEULU BASIN

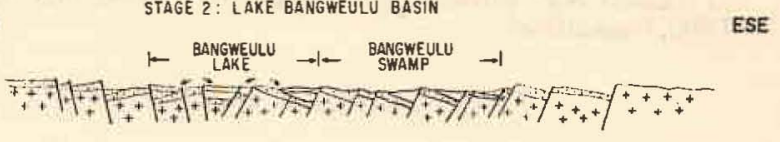

BROTAS GROUP

NNE

STAGE 1: OKAVANGO BASIN

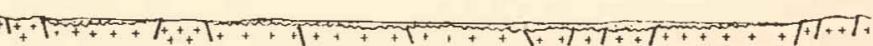

Figure 15 - Comparison between African rifts and Tucano-Jatobá Rift (adapted from Le Fournier 1985)

- lateral thermal flow must be considered, due to the sedimentary filling which acts as an insulating material; this fact explains the low geothermic gradient;

- to the north of South Tucano, the majority of wells were drilled on stable areas, where suitable conditions to generate hydrocarbons did not exist, and so the subbasins were not adequately explored;

- to verify the hypothesis that the rift evolved from a crustal detachment it is necessary to conduct deep seismic surveys, and an integration with the basins of the West of Africa in order to have a global understanding on the rift evolution.

Acknowledgements Many people contributed effectively to this work. We would like to mention Edison J. Milani for his many suggestions and discussions about the evolution of the rift; Ian Davison, who helped us with the theoretical support of the mechanism of transfer faults. Edyr Oliveira, who did the gravimetric inversion and gravimetric modellings showed in this article; Hércules Tadeu da Silva and Augusto C.M. de Castro Jr. for reviewing the manuscript; finally, we thank Petrobras which granted permission to publish this work. 


\section{REFERENCES}

COHEN, C.R. - 1985 - Role of fault rejuvenation in hydrocarbon accumulation and structural evolution of Recóncavo basin, northeastern Brazil. AAPG Bull., 69(1):65-76.

DAVISON, I. \& ARTHAUD, M. - 1987 - Controle estrutural do embasamento Pré-Cambriano sobre a tectônica da bacia de Tucano. Salvador, Petrobrás, (Unpublished).

DELLA PIAZZA, H. \& MUHLMANN, H. - 1963 - Geologia do vale do rio Vaza-Barris - área de Cocorobó e Jeremoabo. Salvador, Petrobrás, (Unpublished) (Relatório 108-1777).

GIBBS, A.D. - 1984 - Structural evolution of extensional basin margins. J. Geol. Soc. London, 141:609-620.

LE FOURNIER, J. - 1985 - Tectonic and sedimentological evolution of the East African rift system. Georift Project. (Unpublished).

LISTER, G.S.; ETHERIDGE, M.A.; SYMONDS, P.A. - 1986 Detachment faulting and the evolution of passive continental margins. Geology, 14(3):246-250.

MILANI, E.J. - 1985 - Tectônica cisalhante na evolução do rift do Recóncavo-Tucano-Jatobá. Rev. Bras. Geoc., 15(4):287-292.

MILANI, E.J. - 1987 - Aspectos da evoluçāo tectônica das bacias do Recóncavo e Tucano Sul, Bahia, Brasil. Rio de Janeiro, Petrobrás/Cenpes. (Ciência-Técnica-Petróleo, Seção Exploração 18).

MILANI, E.J. \& DAVISON, 1. - 1987 - Basement control and transfer tectonics in Recôncavo-Tucano-Jatobá rift, Northeast Brazil. Tectonics. (Submitted).

NETTO, A.S.T.; BRAGA, J.A.E.; SANTOS, C.F.; RIBEIRO, J.C.; CUPERTINO, J.A. - 1985 - Perspectivas exploratórias na bacia do Tucano Sul. Salvador, Petrobrás/Depex-Dexba. (Rel. Int. 1786). Unpublished.
PONTE, F.C.; DAUZACKER, M.V.; PORTO, R. - 1978 - Origem e acumulaçäo de petróleo nas bacias sedimentares brasileiras. In: CONGR. BRAS. PETRÓLEO, 1, Rio de Janeiro, 1978. Anais.. Rio de Janeiro, 18 p. II-121 a I-147.

ROSENDAHL, B.R.; REYNOLDS, D.I.; LORBER, P.M.; BURGESS, C.F.; McGRILL, J.; SCOTT, D.; LAMBIASE, J.J.; DERKSEN, S.J. - 1986 - Structural expressions of rifting: Lessons from Lake Tanganyika, Africa. In: SEDIMENTATION IN THE AFRICAN RIFTS. Quant. J. Geol. Soc. London (Spec. Publ. GSSP 23 in press)

SZATMARI, P.; MILANI, E.; LANA, M.; CONCEIÇĀO, J.C.; LOBO, A. - 1985 - How South Atlantic rifting affects Brazilian oil reserves distribution. Oil \& Gas J. 83(2):107-113.

USSAMI, N.; KARNER, G.D.; BOTT, M.H.P. - 1986 - Crustal detachment during South Atlantic rifting and formation of Tucano-Gabon Basin system. Nature, 322:629-632.

WERNICKE, B. - 1985 - Uniforme sense normal simple shear of the continental lithosphere. Can. J. Earth Sci., 322:108-125.

WILCOX, R.E.; HARDING, T.P.; SEELY, D.R. - 1973 - Basic wrench tectonics. AAPG Bull., 57:74-96.

MANUSCRITO 497

Recebido em 24 de setembro de 1987 Revisão aceita em 26 de fevereiro de 1988

Se não houver frutos

Valeu a beleza das flores

Se nāo houver flores

Valeu a sombra das folhas

Se nāo houver folhas

Valeu a intenção da semente 